\title{
Analysis of Mathematical Reflective Thinking Skills Based on Learning Model And Mathematical Prior Knowledge
}

\author{
Abdul Muin, Lisfa Novianti, Eva Musyrifah \\ Syarif Hidayatullah State Islamic University Jakarta, Jl. Ir. H. Djuanda 95, Ciputat, Indnnesia \\ Corresponding e-mail: abdul.muin@uinjkt.ac.id
}

\begin{abstract}
In several types of research, analysis about mathematical reflective thinking skills viewed based on one independent variable as treatment given. The purpose of the research was to analyze the mathematical reflective thinking skills not only based on learning model but also viewed based on mathematical priorknowledge. The research was conducted at one of state junior high schools in Tangerang Selatan on the academic year 2017. The sample was taken through cluster random sampling technique as many as two classes with the total amount about 72 students. As a treatment, ill-structure problem-solving learning model implemented on experimental class and conventional learning models implemented on control class. Mathematical prior-knowledge was distinguished into three levels: low, middle, and high. Mathematical reflective thinking skills viewed based on three indicators: identifying a problem situation, predicting a solution, and evaluating the situation. Two Way Analysis of Varian has used to analyze the data with the level of significance about 0.05 . The results showed that: 1) there was an effect of learning model towards students mathematical reflective thinking skills overall, 2) there was an effect of mathematical prior-knowledge towards students mathematical reflective thinking skills overall, and 3) there was interactional effect between learning model and mathematical prior-knowledge towards students mathematical reflective thinking skills. In general, the results showed that ill-structured problem-solving learning model contribute to students mathematical reflective thinking skills with a high and middle level of prior-knowledge.
\end{abstract}

Keywords: mathematical reflective thinking, ill-structure problem-solving, prior-knowledge

\section{INTRODUCTION}

Reflective thinking is a very important tool in the process of learning and solving problems. Learning is generally conducted because what will be learned can not be understood. This is a problem, especially in studying mathematics. To solve it needs to learn. In the process of obtaining mathematical understanding or solving mathematical problems occurs the process of thinking reflectively. Thus, the process of learning, thinking reflectively, and solving problems can not be separated. The skills of mathematical reflective thinking become the main tool in the learning process.

The concept of reflective thinking has been raised by John Dewey. Dewey (1910) says that reflective thinking is about the interrelationship between ideas, not just sequences, because from each idea refers to the previous idea and can determine the next result. In the learning process, reflective thinking is related to understanding and creating knowledge (Kapranos, 2007). Muin (2011) states that reflective thinking can be raised in the situation of selection of action or alternative solution, and decision making about action or solution. Reflective thinking is also related to analyzing and making judgment about what was happened (Paden, 2008). According to Muin, Kusumah, and Sumarmo (2012), the process of creating knowledge and making a judgment is formulated by connecting the information previously acquired (prior-knowledge) with new information through intuition. This reflective thinking process will be useful for students. Students not only explore and remember the knowledge they have, but can apply them to create new knowledge and solve 
problems with the most appropriate solution. Even if this skills are developed, the students will get benefit for their live. Shaffer (2015) in her research found that "The ability to think reflectively and critically gives students the power to transform their lives and by extension to positively influence the places where they will work and live".

Nevertheless, most students' reflective thinking skills are still low. The low level of mathematical reflective thinking skills was found in a preliminary study conducted by Nindiasari (2011) in one of Senior High Schools in Tangerang Banten. Its findings show that almost more than $60 \%$ of students have not shown satisfactory results in working on problems that contain indicators of mathematical reflective thinking processes. This result is still consistent with the preliminary research conducted on 39 students at one of the junior high schools in South Tangerang who was asked to solve problems related to mathematical reflective thinking skills. From 39 students, no one answered the question regarding the aspects of evaluating. Overall results from the preliminary studies show that the average of students' mathematical reflective thinking skills only reached $32.26 \%$. In the Program for International Students Assessment (PISA) there are six levels of students' math skills. The achievement of Indonesian students in PISA 2015 only reached $0.8 \%$ from the overall average of $15.3 \%$ (OECD, 2016).

The skills of mathematical reflective thinking need to be developed through learning that can facilitate the understanding of such reflective thinking skills. Learning model that needs to be developed is a learning model that emphasizes the problem-solving process through the strengthening of non-routine problems and demands the students' reasoning in analyzing the problem, as well as finding the most appropriate solution.

One of learning models that emphasize on problem-solving process is ill-structured problemsolving. Ill-structured problem-solving learning is a learning model that emphasizes the problem-solving process which type of problem is ill-structured. The ill-Structured problem is a problem that has an incomplete element and to solve it must first look for certain relevant elements (Hendriana and Sumarmo, 2014). The ill-structured problem has three properties, namely authenticity, complexity, and openness. The authentic issues refer to problems connecting to real life, the complex issues show the problem as a challenge to be resolved, and the openness issue solutions (Hong and Kim, 2016). In practice, the learning model of ill structure problem solving is implemented through stages: analyze \& browse, create, decision-making, and evaluate. (Kim and Cho, 2016).

In addition to the learning model, priorknowledge can influence learning outcomes (Santosa, 2015 and Ertl \& Mandl, 2008). According to Karunia and Yudhanegara (2015), learning can work well if one can adapt new knowledge to the cognitive structure it has. Therefore, considering the students' prior knowledge to manage the learning process is very important.

In several types of research (Zulfikar, 2017 and Hardiyanti, 2017), analysis about mathematical reflective thinking skills viewed based on one independent variable as treatment was given. However, the analyze of mathematical reflective thinking skills not only based on the effect of one variable of learning model as one treatment, but may be also can be influenced commonly with another variable. The purpose of the research was to analyze the mathematical reflective thinking skills based on learning model and mathematical prior-knowledge. The research questions were formulated as: is there the effect of learning model towards students mathematical reflective thinking skills, is there the effect of mathematical prior-knowledge towards students mathematical reflective thinking skills, and is there the interaction effect between learning model and mathematical prior knowledge towards students mathematical reflective thinking skills.

\section{METHODS}

The uniform appearance will assist the reader to read paper of the proceedings. It is therefore suggested to authors to use the example of this file to construct their papers. This particular example uses an American letter format with $25 \mathrm{~mm}$ margins left, right, top and bottom.

All text paragraphs should be single spaced, with first line intended by $7 \mathrm{~mm}$. Double spacing should NOT be used anywhere in the manuscript. Position and style of headings and subheadings should follow this example. One empty line (11 pt) should be left between every two consecutive sections. Two empty lines should be left before and after the abstract.

All headings and subheadings should be bold and Arial font. Major headings must be $12 \mathrm{pt}$ and subheadings should be $11 \mathrm{pt}$. No empty lines are required between the heading/subheading and the text.

\subsection{Research Design}

The method used in this research is quasi-experiment. This research was conducted by dividing the group 
into two groups of observation, that is experiment group (group that was given the learning with illstructure problem-solving model) and control group (group that was given with conventional model). The research design used was Randomized post-test only control group design.

In this research, the process of solving illstructured problems is adapted from Kim and Cho (2016) which is divided into 4 stages: Analyze \& Browse, Create, Decision-Making, and Evaluate. In the Analyze and Browse stage, students are guided to analyze the problem of the information provided, and then the students are also guided to read and understand the problem situation through problem analysis. In the Create Stage, students are guided to make various plans to solve the problem. In the Decision Making stage, students are guided to be able to find and determine the most appropriate solution of some solutions that have been obtained. In the Evaluate stage, students are guided to assess the problem-solving process that will be the final solution.

The mathematical prior-knowledge (MPK) of students in this study is referred to the initial knowledge of mathematics before the students are given the treatment of learning. The measurement of MPK is based on the results of three daily tests and a mid-exam before the treatment is given. Grouping of MPK was distinguished into three levels namely low category, medium category, and high category. This grouping is based on the mean and standard deviation of the student's overall MPK score.

\subsection{Sample}

The research was conducted at one of state junior high schools in Tangerang Selatan on the academic year 2017. The sample was taken through cluster random sampling technique as many as two classes with the total amount of 72 students. As treatment, ill-structure problem-solving learning model implemented on experimental class with the total amount of 36 students and conventional learning models implemented on control class with the total amount of 36 students too.

\subsection{Research Instrument}

The instrument to measure mathematical reflective thinking skills (MRTS) viewed based on three indicators: identifying problem situation, predicting solution, and evaluating the situation. The number of MRTS test are six questions items with each indicator consists of two questions items.

\subsection{Technique of Data Analysis}

Data were collected based on two-factor variables, learning model with two level (Ill-Structure ProblemSolving and Conventional), and mathematical priorknowledge with three level (low, medium, and high). Two Way Analysis of Variance was used to analyse the data with a significance level of 0.05 . Data processed using SPSS ver. 23.

\section{RESULTS DAN DISCUSSIONS}

\subsection{Mathematical Reflective Thinking Skills}

The research was conducted in two classes of grade VIII in one of State Junior High School in South Tangerang. One class as experiment group and other class as control group. The sample of research in this study amounted to 72 students, with 36 students in the experimental group and 36 students in the control group. The learning process in the experimental group uses the ill-structured problem-solving (ISPS) model, while the control group uses conventional learning (CL) model. The subject matter taught in this research is a flat side space geometry.

Student's mathematical reflective thinking skills (MRTS) analysed based on learning model (LM) and mathematical prior-knowledge (MPK). The learning model consist of ill-structure problem-solving (ISPS) and conventional learning (CL). The MPK level consist of low, medium, and high category.

The study was conducted in nine sessions in each class, with eight learning sessions on the material of flat side space geometry, and one last session for MRTS posttest. Table 1 presents the data on MRTS test results that are described based on the learning model and MPK in both groups, and the interaction between the learning model and MPK. 
Table 1. Descriptive statistics of students' mathematical reflective thinking skills

\begin{tabular}{|c|c|c|c|c|}
\hline \multirow{2}{*}{ MPK } & \multirow{2}{*}{ Statistic } & \multicolumn{2}{|c|}{ Learning Models } & \multirow{2}{*}{ Overall } \\
\hline & & ISPS & $\mathrm{CL}$ & \\
\hline High & $\begin{array}{c}\bar{X} \\
s \\
n\end{array}$ & $\begin{array}{c}67.86 \\
10.41 \\
7\end{array}$ & $\begin{array}{c}48,96 \\
9,24 \\
4\end{array}$ & $\begin{array}{c}58,41 \\
9,83 \\
11\end{array}$ \\
\hline Medium & $\begin{array}{c}\bar{X} \\
s \\
n\end{array}$ & $\begin{array}{c}58.73 \\
8.88 \\
21\end{array}$ & $\begin{array}{c}44,27 \\
8,23 \\
24\end{array}$ & $\begin{array}{c}51,50 \\
8,56 \\
45\end{array}$ \\
\hline Low & $\begin{array}{c}\bar{X} \\
s \\
n\end{array}$ & $\begin{array}{c}43,23 \\
3,82 \\
8\end{array}$ & $\begin{array}{c}41,67 \\
8,33 \\
8\end{array}$ & $\begin{array}{c}42,45 \\
6,08 \\
16\end{array}$ \\
\hline Total & $\begin{array}{l}\bar{X} \\
s \\
n\end{array}$ & $\begin{array}{c}56,61 \\
7,7 \\
36\end{array}$ & $\begin{array}{c}44,97 \\
8,60 \\
36\end{array}$ & $\begin{array}{c}50,79 \\
8,15 \\
72\end{array}$ \\
\hline
\end{tabular}


Based on Table 1, the average value of MRTS is highest in the group of students who have high level of MPK by using ISPS learning model that is equal to 67.86. Then the average value of MRTS in second highest is in the group of students who have medium level of MPK by using ISPS learning model too, and the value is 58.73. The MRTS average value of the medium level of MPK in ISPS group is higher than the MRTS average value of high level of MPK in the conventional group, which only reached 48.96. These results indicate that MRTS of the high level of MPK in the conventional group is still lower than the MRTS of the medium level of MPK in ISPS group, even much lower when compared to the high level of MPK in the ISPS group. While the average value of MRTS for the low level of MPK, both in ISPS group and conventional group get the average value that is not much different, that is equal to 43,23 and 41,67 , where the difference of the average of both is only equal to 1,56 .

From the comparison of the average values of MRTS in the ISPS group and the conventional group based on the MPK level of the students, overall the average value of MRTS at each level of MPK, students MRTS score in ISPS group is higher than the conventional group. This indicated the notion of the interaction between learning model and MPK.

\subsection{Data Analysis}

The following is presented the results of hypothesis testing on the influence of implementation of learning model (LM) and mathematical prior knowledge (MPK) to students' mathematical reflective thinking skills.

Table 2. The results of two-way analysis of variance of students' mathematical reflective thinking skills

\begin{tabular}{lrrrrr}
\hline Source & Sum of Squares & Df & Mean Square & F & Sig. \\
\hline Corrected Model & $5517,80^{\mathrm{a}}$ & 5 & 1103,56 & 16,42 &, 000 \\
Intercept & 126819,90 & 1 & 126819,9 & 1887,06 & 000 \\
LM & 1665,70 & 1 & 1665,70 & 24,78 &, 000 \\
MPK & 1718,47 & 2 & 859,23 & 12,78 &, 000 \\
LM ${ }^{*}$ MPK & 624,06 & 2 & 312,03 &, 013 \\
Error & 4435,52 & 66 & 6,64 & \\
Total & 194567,52 & 72 & & \\
Corrected Total & 9953,33 & 71 & & \\
\hline
\end{tabular}

a. R Squared $=, 554$ (Adjusted R Squared $=, 521$ )

Based on Table 2, the main factors of learning model and MPK are very significant influence on MRTS. Likewise, the interaction between LM and MPK is significant enough to influence MRTS. ISPS contributes more to MRTS than CL. Since there are three level of MPK then to see which MPK level is most influential is a post hoc test, i.e. comparing the MRTS of each level of MPK pair using Schefee test. Table 3 shows the results of the post hoc test.

Table 3. The Post hoc results

\begin{tabular}{llrll}
\hline \multirow{2}{*}{ (I) MPK } & (J) MPK & $\begin{array}{c}\text { Mean } \\
\text { Difference } \\
(\mathrm{I}-\mathrm{J})\end{array}$ & $\begin{array}{c}\text { Std. } \\
\text { Error }\end{array}$ & Sig. \\
\hline \multirow{2}{*}{ Low } & Medium & $-8,5699^{*}$ & 2,38616 &, 003 \\
& High & $-18,5358^{*}$ & 3,21089 &, 000 \\
\multirow{2}{*}{ Medium } & Low & $8,5699^{*}$ & 2,38616 &, 003 \\
& High & $-9,9659^{*}$ & 2,75735 &, 003 \\
\multirow{2}{*}{ High } & Low & $18,5358^{*}$ & 3,21089 &, 000 \\
& Medium & $9,9659^{*}$ & 2,75735 &, 003 \\
\hline
\end{tabular}

Based on Table 3, comparing each pair of MPK level on significance level of 0.05 give the significant results overall. These results indicated that the sequence of MRTS score increasingly from Low to high (Low $<$ Medium $<$ High). The high level of MPK have the highest MRTS score then the medium and low level of MPK. However, the interaction between LM and MPK is significant. There is the effect of interaction between LM and MPK to students MRTS. For more clearly the interaction between LM and MPK described on Figure 1.

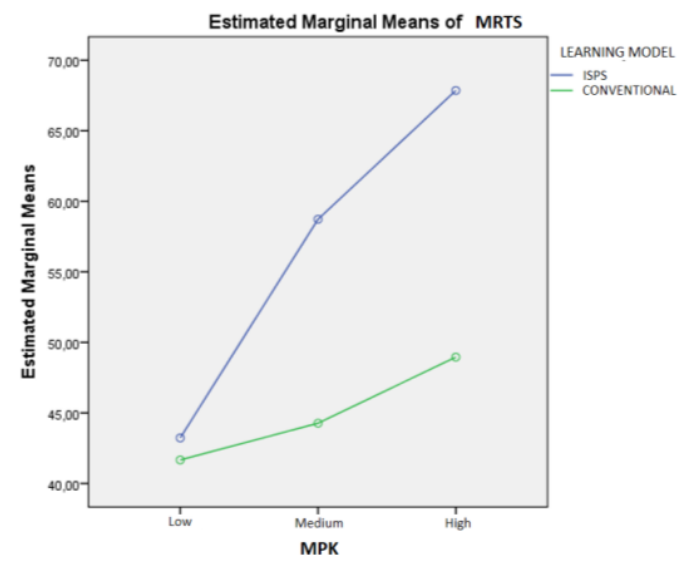

Figure 1. Graph of interaction between LM and MPK. 
Figure 1 shows that at the low level of MPK, the average of student's MRTS score is almost equal either ISPS learning model or conventional learning model. For medium and high level of MPK, the difference in mean score of student MRTS is quite large.

\subsection{Discussions}

The first results of the research showed that there was effect of learning model towards students mathematical reflective thinking skills overall. The results of this study indicate that the ill-structured problem-solving model can contribute to the development of mathematical reflective thinking skills. This is in line with research conducted by Hong \& Kim (2016) which states that the level of students' mathematical abstraction skills can be increased with ill-structured problem-solving.

In the individual activity is conducted by stages of analyze the problems and information provided, as well as looking for solutions to the given problem (analyze $\&$ browse, create). Then small group activity is conducted by repeating the stages of analyze \& browse, create, where each member in the group discusses and expresses the ideas gained into the group, followed by the decision-making stage, then continued by reassessing and making sure whether the solution is correct or not (evaluate). While the overall activity (plenary activity) only repeats the evaluate stage, the students representing each group present their answers to get the best answer. This is also relevant to the opinion of Mirzaei, Phang, \& Kashefi (2014).

The second results of the research showed that there was effect of mathematical prior-knowledge towards students mathematical reflective thinking skills overall. This results shows that there is an average difference between MRTS for each MPK level of students in both classes. This indicates that the MPK level of the student can influence the result of mathematical reflective thinking skills. These results support the research conducted by Muchlisin (2010) recommendation to obtain the information about the experience of the students, to provide teaching materials that are more relevant to the students' knowledge.

The third results of the research showed that there was interactional effect between learning model and mathematical prior-knowledge towards students mathematical reflective thinking skills. Groups of students who have medium and high level of MPK who use ISPS model in the learning process, apparently obtain higher results than students in the conventional group with the same level of MPK. While in the group of students who have low level of MPK, mathematical reflective thinking skills of the two classes looks the difference is not too significant.

\section{CONCLUSIONS}

Based on the results of analysis and discussion of research on the influence of ill-structured problemsolving model and mathematical prior-knowledge on the mathematical reflective thinking skills, obtained some conclusions. 1) There was effect of learning model towards students mathematical reflective thinking skills overall, 2) there was effect of mathematical prior-knowledge towards students mathematical reflective thinking skills overall, and 3) there was interactional effect between learning model and mathematical prior-knowledge towards students mathematical reflective thinking skills. In general, the results showed that ill-structured problem-solving learning model contribute to students mathematical reflective thinking skills with the high and the middle level of prior-knowledge.

\section{ACKNOWLEDGEMENTS}

The authors wish to thank Faculty of Education Sciences UIN Syarif Hidayatullah Jakarta

\section{REFERENCES}

Dewey, J. (1910). How we think, Lexington, Mass: D.C. Heath.

Ertl, B., Mandl, H. (2008). "Effects of individual prior knowledge on collaborative knowledge construction and individual learning outcomes." Proceedings of the Conference Knowledge Construction in E-learning Context: CSCL, ODL, ICT and SNA in Education, September 2008, 398.

Hardiyanti. (2017). Pengaruh context based learning terhadap kemampuan berpikir reflektif matematis siswa. Thesis. Syarif Hidayatullah State Islamic University of Jakarta from http://repository.uinjkt.ac.id/dpace/handle/12345 6789/34722.

Hendriana, H., Sumarmo, U. (2014). Penilaian pembelajaran matematika. Bandung: PT Refika Aditama.

Hong, J. Y., Kim, M. K. (2016). Mathematical abstraction in the solving of ill-structured problems by elementary school students in Korea. Eurasia Journal of Mathematics, Science \& Technology Education, 12(2), 267-281. 
Kapranos, P. (2007). 21 $1^{\text {st }}$ Century teaching \& learning: Kolb Cycle \& reflective thinking as part of teaching, creativity, innovation, enterprise and etics to engineers. International symposium for engineering education, Dublin City University, Ireland.

Karunia, E. L., Yudhanegara, M. R. (2015), Penelitian pendidikan matematika. Bandung: PT Refika Aditama.

Kim, M. K., Cho, M.K. (2016). Pre-service elementary teachers' motivation and ill-structured problem solving in Korea. Eurasia Journal of Mathematics, Science \& Technology Education, 12(6), 1569-1587, doi: 10.12973/eurasia.2016.1246a.

Mirzaei, F., Phang. F.A., Kashefi, H. (2014). Measuring Teachers Reflective Thinking Skills. Procedia - Social and Behavioral Sciences 141, $640-647$

Muchlisin. (2010). Hubungan antara kemampuan awal matematika dan motivasi berprestasi dengan hasil belajar matematika materi segitiga dan segiempat kelas VII SMP Askhabul Kahfi olaman Mijen Semarang Tahun 2009/2010, Thesis, IAIN Walisongo, Semarang.

Muin, A. (2011). The Situations that can bring reflective thinking process In mathematics learning. Proceeding of International Seminar and the Fourth National Conference on Mathematics Education. Department of Mathematics Education, Yogyakarta State University, Yogyakarta, July 21-23.

Muin, A., Kusumah, Y.S., Sumarmo, U. (2012). Mengidentikfikasi Kemampuan Berpikir Reflektif Matematis, Prosiding konferensi nasional matematika.XVI IndoMS. Jatinangor: Universitas Padjadjaran, 1354.

Nindiasari, H. (2011). Pengembangan bahan ajar dan instrumen untuk meningkatkan berpikir reflektif matematis berbasis pendekatan metakognitif pada siswa sekolah menengah atas (SMA). Prosiding Seminar Nasional Matematika dan Pendidikan Matematika FMIPA. UNY. ISBN : 978-979-16353-6-3. hh. 251-263.

OECD. (2016). PISA 2015 Results (Volume I): Excellence and Equity in Education. Paris: PISA, OECD Publishing. http://dx.doi.org/10.1787/ 9789264266490-en

Paden, N. (2008). What was I thinking? Encouraging reflective thinking in the classroom through exam question appeals. Proceeding of $A S B B S, 15(1)$, 1212-1216.
Santosa, P.I. (2015). Student Engagement with Online Tutorial: A Perspective on Flow Theory. IJET, 10(1), $60-67$.

Suzanne, C. Shaffer, M. Ed., M. S. Ed., (2015). Building Student Capacity for Reflective Thinking. The Common Good: A SUNY Plattsburgh Journal on Teaching and Learning, 3. http://digitalcommons.plattsburgh.edu/ commongood/vol3/iss $1 / 3$

Zulfikar, A. (2017). Pengaruh Moel pembelajaran MASTER terhadap kemampuan berpikir reflektif matematis siswa. Skripsi, UIN Syarif Hidayatullah Jakarta. available online http://repository.uinjkt.ac.id/dpace/handle/12345 $\underline{6789 / 33733 .}$. 